\title{
Biblical principles as an answer to the African people's questioning of witchcraft
}

\author{
Authors: \\ David K. Semenya \\ Rantoa Letsosa \\ Affiliations: \\ ${ }^{1}$ Department of Practical \\ Theology, Unit for Reformed \\ Theology, North-West \\ University, Potchefstroom \\ Campus, South Africa \\ Correspondence to: \\ Rantoa Letsosa \\ Email: \\ rantoa.letsosa@nwu.ac.za \\ Postal address: \\ PO Box 736, Fourways North \\ 2086, South Africa \\ Dates: \\ Received: 23 Aug. 2011 \\ Accepted: 10 Sept. 2012 \\ Published: 24 Oct. 2012 \\ How to cite this article: \\ Semenya, D.K. \& Letsosa, \\ R., 2012, 'Biblical principles \\ as an answer to the African \\ people's questioning of \\ witchcraft', Verbum et \\ Ecclesia 33(1), Art. \#674, \\ 8 pages. $\mathrm{http}: / / \mathrm{dx}$.doi. \\ org/10.4102/ve.v33i1.674
}

C 2012. The Authors

Licensee: AOSIS

OpenJournals. This work

is licensed under the

Creative Commons

Attribution License.
Witchcraft is still an enormous and serious issue in African culture. The media, including the entertainment component (e.g. African Magic programmes on satellite television), portray witchcraft as an issue that needs to be addressed. Witchcraft has in a sense been integrated into the system and context of the Nigerian community because most of the programming originates from this country. The same can be said of the South African milieu. It would be remarkable to read a tabloid such as the Daily Sun without at least one reference to witchcraft. Between 1994 and 1996 several hundred people were killed in the Limpopo Province on suspicion of witchcraft, to which the response from the Christian sector was diverse and varied. De Vries (2010:35) argues that Christians believe that upon becoming a member of this faith, witchcraft is powerless; yet there are indeed Christians who consider bewitchment possible, despite a belief in God. This being the case, the question that arises is, 'What does the Bible teach in this regard'? The most compelling evidence for the existence of witchcraft is its mention in both the Old Testament (OT) and the New Testament (NT). Although all Christians read the same Bible, the interpretation of its teachings on witchcraft differ greatly. This article has attempted to identify, from a historical-grammatical exegetical point of view, a number of biblical principles on witchcraft that could be set as guidelines for addressing witchcraft-related matters and to obtain a clearer picture on Scripture's teachings regarding witchcraft. (This topic has also been explored from a meta-theoretical perspective in a follow-up article.)

\section{Introduction}

A number of studies have been conducted on witchcraft from a range of perspectives, including the theological. Given this point, the authors of this article would like to give credit to works relating to witchcraft such as Van Rooy's Witches and wizards in the light of Scripture (1973:136138); Kotze's The witch in Psalm 59 (2008:383-390) and Kotze's The evil eye as witchcraft technique in the Hebrew Bible (2007). However, biblical principles did not form part of these writers' research scope. In view of this, the authors of this article would like to note that it may indeed be this failure to provide biblical principles on witchcraft that could be giving rise to the uncertainty surrounding this topic in Africa. The aim of this article is thus to provide biblical principles that will ease the concerns regarding witchcraft. This article's approach is based on practical theology, which stands on three legs (cf. Letšosa 2005:12-14). The first leg studies the context (praxis 1) to determine how much of a problem witchcraft is at present (meta-theory). The second leg identifies biblical principles for dealing with a problem situation and the third leg facilitates communication or interaction between the meta-theory and the basis-theory to formulate a new praxis theory, which would eventually lead to praxis 2 .

This article, however, mainly hops on one leg and focuses on praxis 1, which acknowledges that witchcraft ${ }^{1}$ is indeed a problem issue, hence the formulation of the basis theory. The basic principles are not only intended to form the foundation for further study and for improved integration between the biblical principles and the meta-theory, but also to set guidelines that may be utilised to shed light on the biblical (Old Testament and New Testament) approach to witchcraft.

\section{The biblical definition of witchcraft}

The Old Testament (OT) word for witch is but it is usually associated with sorcery and divination (note: divination is also a separate study field). Witchcraft relates to mysterious interaction with another world. Achtemeier (1985:1137) defines a witch as a specialist in the manipulation of intangible powers of evil against people. The Hebrew language describes witches as practitioners in magic and incarnations or jugglers who

1.The authors want to bring to the attention of the reader that they acknowledge the fact that there are many agents that the devil uses to further his deeds which link themselves with witchcraft such as sorcery (a practising witch), demons, magic and practices such as occultism, etcetra. All these are agents of the devil. 
pretend, through skill in occult science, to reveal the future. The word is in the feminine gender because many women became involved in the mystic arts at that time. This does not, however, indicate that witchcraft was exclusively practiced by women in OT times, but rather that female witches proved more seductive than their male counterparts (cf. Easton 1996; Strong 1996).

Girdlestone (1998:297) argues that witchcraft was adopted in the very early days as a method of trading upon the religious instincts and superstitions of mankind and that it was largely conducted by the female sex, although not confined to it. A few texts in the OT that make reference to witchcraft are Exodus 22:18 and Chronicles 33:6.

The Exhaustive Concordance of the Bible mentions that the American version translates the Greek word pharmakeia in two cases as 'sorcery' and in another case as 'witchcraft'. In the Greek context pharmakeia also relates to the administering of drugs, poisoning and sorcery or magical arts often linked to idolatry and fostered by it. Metaphorically it refers to the deception and seduction of idolatry. In support of the aforesaid statement the New Testament (NT) in Galatians 5:20b-21 and Revelations 21:8, strongly denounces this as one of the sinful works of the flesh.

Hayes (1995:339) describes witchcraft as the supposed power of a person to inflict harm on others through occult or by supernatural means. In the contemporary traditional South African context, Kgatla (1995:21-22) differentiates between two types of witches: night witches and day witches. The authors would like to state that because witchcraft remains a problem in society to this day, an updated view and definition of the African perspective on witchcraft was required and duly formulated in a previous article on the subject. Comparatively, the authors' definition correlates with Scripture's view on witchcraft, as defined under the heading 'The biblical definition of witchcraft' ${ }^{2}$.

\section{The African view on witchcraft}

It should be noted that Africans believe in the existence of witchcraft and as such it has a certain impact on their lives. According to Nyirongo (1997:86) witchcraft is thus considered both valuable and evil to Africans. It is valuable in the sense that it provides the necessary power to protect the family and yet, in his exploration of the evil side to witchcraft, Nyirongo shows how Africans ascribe all the ills, misfortunes, sicknesses, accidents, tragedies, sorrows, dangers and

2.Africans view witchcraft as something evil and potentially harmful to others. It is thus unsurprising that anyone suspected of practising witchcraft within the community is either killed or harassed in different ways by members of the community. This is evident in many parts of the countries that make up the African continent, including South Africa. Khunou (2001) defines witchcraft as a satanic spiritual powe practised by thousands of people, knowingly or otherwise, in order to advance the kingdom of Satan. It includes verbal abuse and magical spells in which the result is always the same: devastation, poverty, divorce, mental derangement and mental slavery. Witchcraft is the supposed power of a person to harm others by occult slavery. Witchcraft is the supposed power of a person to harm others by occult or by supernatural means (Hayes 1995:339). Trapido (2010), however, reports that self-proclaimed witches have rejected such definitions, as pointed out by Khunou and Hayes, on the grounds that these types of definitions stereotype witchcraft as harmful and portray witches as a danger to the communities within which they live and work. Nevertheless, Basotho culture maintains that witchcraft is detrimental practice that can bring evil, bad luck and poverty into their lives, which is why they respond with violence towards those suspected of practising witchcraft (Hayes 1995) confusing mysteries they encounter or experience to the mystical power in the hands of a sorcerer, witch or wizard. This explains why, for instance, a bereaved mother of a child who dies from malaria would not be satisfied with the scientific explanation that a malaria-carrying mosquito stung her child which led to his or her suffering and death.

Correspondingly, Mbiti (1991:166) further argues that the aforesaid belief about witchcraft is found in all African societies and is no trifling matter in Africa. The challenge that thus arises is how the African should interpret God's role in terms of witchcraft. Does God allow witchcraft or does he oppose such acts? If yes, does he allow it to happen to all people or only Christians? Should Christians live in fear of been bewitched? The stance of many African Christians on witchcraft has been clearly indicated from observation and research that the authors have already conducted in another article on the meta-theoretical assumption on witchcraft. In that article it is indicated that even some church members in times of difficulties would visit witchdoctors for protection or revenge, depending on the information they received with regard to their misery. This article mainly reviews how God addresses the topic of witchcraft in his Word and how those who believe in him should address questions regarding witchcraft.

\section{Work plan}

The abovementioned review will entail the study of a number of books from both the OT and the NT. Principles from each periscope will be pinpointed, beginning with those found in the OT and followed by those of the NT. Furthermore, a Scriptural picture on the teaching of witchcraft, from a revelatory historical point of view, will be presented and subsequently followed by practical guidelines.

\section{Basic principles on witchcraft in the Old Testament Exodus 22:18}

The main emphasis herein falls on the treatment of witchcraft practitioners. Exodus 22:18 reads, 'Do not suffer a witch to live'. Walvoord and Zuck (1985) show how verse 18 neatly fits into the laws intended to govern the Hebrews. According to Walvoord and Zuck (1985), the ancient rabbis found 613 specific laws in the Pentateuch. In a section titled 'The book of the covenant' (Ex 20:22-23:13), a number of these 613 laws are listed. They illustrate and thus help to explain the basic implication of the Ten Commandments for members of the covenant community. These specific laws can be grouped according to general content, namely, (1) laws governing treatment of Hebrew servants (Ex 21:1-11), (2) compensation for personal injury (Ex 21:12-13), (3) restitution for violation of property rights (Ex 22:1-5) and (4) laws that deal with the various responsibilities of the members of the covenant community (Ex 22:16-31). The important truth this collection of laws illustrates is firstly, that God is deeply concerned with every aspect of the believer's lifestyle and secondly, that the basic Ten Commandments have the broadest possible 
application. It necessitates sensitivity to their implication for every choice made and for every law that our society enacts.

In the same way, Jamieson, Fausset and Brown (1997:369) add that these laws are not a collection of pedantic rules, but are collectively a case study of God's principles in action. God took potential situations and demonstrated the practical application of His laws in the Israelites' everyday lives. Moreover, the laws that follow from verse 18 of Chapter 20 onwards differ both in form and in subject matter (Richards 1991). They make demands, however, on Israel on the grounds of its election as the holy nation of Jehovah. The transition from the former series to the present one is made by the command in verse 18 that stipulates, 'Do not allow a witch to live'. Witchcraft is depicted here as the vilest way of harming a neighbour and their property.

'Thou shall not allow or suffer a witch to live' is a strong expression, adopted apparently to prevent the interposition of any false sympathy or misplaced tenderness towards a person of such character. In fact, such individuals were to be rooted out from amongst the Israelites because witchcraft was considered a capital offence and an act of rebellion against God and his authority; in essence, it was siding with Satan in opposition to God (The Interpreter Bible 1995:1006; The Life Application Bible 1999:141). Clements (1972:145) adds that any form of witchcraft practice was strongly opposed in Israel, on religious grounds, because it implied a use of the supernatural outside of and hostile to the power of God. As such, the religion of Yahweh demanded absolute loyalty. A few principles can be deduced from this exegesis.

\section{Principles from Exodus 22:18}

- The Lord demands absolute loyalty and does not tolerate any involvement with other gods or spirits.

- Witchcraft teams up with Satan in opposition to God.

- Witchcraft implies a use of supernatural forces outside of and hostile to the power of God.

- Practitioners of witchcraft were to be exterminated.

\section{Deuteronomy 18:10-12}

The second Scriptural passage to be reviewed is Deuteronomy 18:10-12, which prohibits any form of participation in witchcraft practices and says, 'Let no one be found among you who sacrifices his son or daughter in the fire, or casts spells, or who is a medium or who consults the dead'. In Deuteronomy 18:10b-12 God gives a comprehensive list of witchcraft practices Israel was to avoid in order to maintain pure worship. In fact, each time God's messengers came into conflict with pagan rulers it was always the magicians, sorcerers and the diviners who rose up to challenge them (Nyirongo 1997:188-189).

As can be seen from the above, witchcraft always features some sort of evil act intended to bring harm to others. As a result God highlights the various practices in these verses that the children of Israel were to avoid to ensure a righteous relationship with God and each other.
The next point in this argument centres on how God was actively involved in the lives of the Israelites by ordaining leaders (in addition to the local elders, priests and legal experts) comprising the Supreme Court and the king (Walvoord \& Zuck 1985). These included ordinary priests and Levites, who served brief shifts at the central sanctuary (Deut 18:1-8). Most notable amongst these were prophets who acted as God's contemporary spokesmen to his people. Israel was thus to refrain from seeking supernatural guidance from an occult source (Deut 18:9-13) because God provided the necessary guidance beyond that already contained in Scripture through his prophets (Deut 18:14-22). A true prophet of God could be recognised in three ways: he would be a Jew (Deut 18:15), he would speak in the name of the Lord (Deut 20) and his prediction(s) would surely come to pass (Deut 18:22). Israel was to have nothing to do with witchcraft practitioners (Deut 18:14).

This verse makes it once again clear how all forms of witchcraft, sorcery, divination or pretence were considered to be blatant professions and practices of idolatry (Jamieson, Fausset \& Brown 1997:369). Witches feigned the knowledge and power to commit supernatural acts by virtue of supernatural powers bestowed by the deities with whom they supposedly had direct and intimate contact and which the Hebrew government regarded as high treason. They openly denied Jehovah to be the one true God. Their evil acts claimed the power of idols and with such acts they intended to depose Jehovah as the King of Israel by asserting the authority of 'other gods' before him.

Every form of divination, whether from occult or natural objects, as well as the communion with the dead and all forms of magic were to be utterly rooted out (cf. Phillips 1973:125). In fact, the third commandment prohibits resorting to magic as a means of divination. The following can thus be deducted from this passage:

\section{Principles from Deuteronomy 18:10-14}

- In support of the third commandment, witchcraft practices are to be rooted out.

- God's people must avoid any contact with witchcraft practices because this would be an act of idolatry and is also forbidden by the first commandment.

- The power of witchcraft clearly comes from other deities, rather than from God.

- Witchcraft denies God as the only true God, thus witchcraft practices are punishable by God.

\section{Kings 9:1-29 and 2 Kings 21:1-10}

Although God had put in place leaders to guide his people, there were a number of leaders who instead of guiding people in the right direction, led them astray. The book of Kings recounts how some of the kings of Israel participated in or allowed witchcraft practices within their realms. An example of such disobedience is Jehu's confrontation of Joram concerning his practising of witchcraft. In 2 Kings 9:22 Jehu declares to Joram that, 'So long as the whoredoms of your 
mother Jezebel and those much witchcraft of hers continues, there will be no peace' (cf. Spence \& Exell 1950:192).

Hazael and Jehu were the designated instruments of God's justice in punishing and destroying the house of Ahab. Elijah was told to appoint them to this service, but upon Ahab's humiliation a reprieve was granted and it was left to Elisha to appoint them (Keil \& Delitzsch 2002). The preceding verses relate the anointing of Jehu as king. Jehu speedily fulfilled his duties (2 Ki 21:1-10), specifically by confronting Joram over her mother's whoredoms and witchcraft practices, as well as explicitly telling him that there would be no peace as long such practices continued in that land (Henry 1996).

Likewise, in 2 Kings 21:1-10, verses 1, 6 and 9 particularly recount the history of Manasseh who followed the example of his grandfather, Ahaz, instead of his father (most probably motivated by the desire for stature and power as well as to instil fear in his followers) thereby angering God with occult practices, including sorcery and divination as well as consulting mediums and spiritists.

It is important to mention that personal gain was often the motive behind these leaders' allowance of or participation in witchcraft. It could also be suggested that in allowing witchcraft in their kingdoms, they in fact promoted it and consequently their conduct prevented harmony with God.

\section{Principles from 2 Kings 9:1-29}

- Where there is witchcraft, there is no peace with God.

- God punishes those who practice witchcraft and his punishment may even have an impact on the land, not only its people.

- God forbids the practice of witchcraft aimed at gaining power and prosperity.

\section{Samuel 28:1-25}

It is also important to understand that most of these kings participated in witchcraft out of desperation and impatience, leading to the conclusion that their lives centred on the zealous promotion of their own interests. Although the actions of these leaders cannot be condoned, it does demonstrate how desperation and impatience can lead to sin. A closer look at the closing chapters of 1 Samuel describes a single major event, namely, a fierce battle between Israel and the Philistines, including the actions and fortunes of the three parties involved: Saul and the Israelite army; the Philistine army; and David and his smaller army (Walvoord \& Zuck 1985). Israel was in grave danger and Saul was in desperate need of military advice. Although the history is depicted in personal terms, it is important to realise that Saul was seeking guidance as the ruler of Israel and not as a private individual. Yet even as king, he was at a loss. Saul source for prophetic guidance, Samuel, had recently died and the only way he could seek his advice was through a medium.

Saul had, however, driven all mediums out of the central part of his realm, upholding the OT laws that stringently opposed necromancy (consulting the dead) (cf. Lv 19:31; Deut 18:9-14). The fact that Saul resorted to such measures reflected his desperation and entailed him travelling as far north as Endor, at the far side of the Philistine camp.

The account of this history is intended to emphasise Saul's hopelessness and to show how low he had sunk in turning to a criminal for comfort - the woman concerned was after all considered a criminal by Saul's own laws. The chapter does, however, not endorse the practices of mediums and is in no way a source from which to seek God's guidance.

This section presents what another writer considered to be perhaps the darkest moment in Saul's life: his deliberate violation of one of the most serious prohibitions in the Torah (cf. 1 Chr 10:13-14). Saul had, by turning to a medium for guidance, committed a capital offence (cf. Lv 20:6) and less than 24 hours later, he died - a sobering reminder of the swiftness and surety of the Lord's punishment for anyone who violates the divine Word (Carson 1994:80).

After all, occult practices (divination, sorcery, witchcraft, mediums, spiritists or consulting with the dead such as a witch of Endor) make Satan and his demons the source of information (The Life Application Bible 1999:485). Thus, in order to keep from committing evil before the Lord, Saul outlawed the sinful deeds of spirits, mediums and witchcraft. In desperation, however, he eventually turned to one for counsel. He may have removed the sin of witchcraft from the land, but he did not remove it from his heart.

Thus, Letšosa (2005:230) rightly states that the dead are not truly communicating with the living in these cases, but that it is simply a number of evil spirits feigning to be the real deceased. God does not use the departed to proclaim his message, but makes use of the living. The idea that God requires the aid of the dead, referred to as 'god', actually despises God and refutes his power to act alone.

\section{Principles from 1 Samuel 28:1-25}

- One must not seek counselling from the dead.

- One must have faith in God, even in the most adverse of circumstances.

- Seeking counsel from practitioners of witchcraft is equal to consulting Satan for aid.

- Witchcraft is not only to be despised, but must also be removed from the heart.

\section{Micah 5:11}

The above account seems to demonstrate that God not only opposes witchcraft, but also promises to destroy it. The final analysis of the book of Micah 5:11 clearly reflects the Lord's anger, 'The Lord says, 'I will destroy your witchcraft and you will no longer cast spells"'. During the time of the prophet Micah many people believed in their own power and that of witchcraft. The Lord could no longer tolerate this and thus promised that in punishment for their evil practices, he would destroy their witchcraft (Wiseman 1988:189). The 
implication, within this context, could be that their magic would become powerless.

It could be concluded that verses 10-14 embody a prophecy because it begins with 'I will destroy ...' (Mi 5:10-13) and is God's answer to the prayer in verse 9. The Hebrew verb translated as 'destroy' frequently refers to the removal of those who violated Israel's holiness (e.g. 'cut off' in Lv 17:10; 20:3-6). This involved taking steps to preserve Israel in the face of God's wrath against the unholy. These objects, the works of their own hands, consigned to annihilation from amongst them (Mi 5:10, 13,14) threatened Israel's faith in God, namely, military might (Mi 5:10-11; cf. Deut 17:161-7), sorcery (Mi 5:12; cf. Deut 18:9-13) and idolatry (Mi 5:13-14; cf. Deut 7:5). Isaiah (Is 2:6-8) accused Israel of placing their confidence in these very things. Military hardware included the offensive horse-drawn chariots (Micah 5:10), the defensive cities and all the strongholds (Mi 5:11). The New International Version (NIV) Bible omits the phrase 'from your hand' after the word 'witchcraft' from verse 12, a phrase that emphasises that they are human fabrications. Verse 13 makes the same point in reference to carved images and sacred stones, the stylised representations of the male deity Baal.

\section{Principles from Micah 5}

- Witchcraft is a form of human fabrication. It is not a gift from God.

- In God's sight, witchcraft is powerless and he promised to destroy it.

\section{Summary of Old Testament principles regarding witchcraft}

- The Lord demands absolute loyalty and does not tolerate any consultation with other spirits. He condemns engagement in the practice of witchcraft (also cf. the third commandment).

- Witchcraft power comes from Satan, because it implies a use of supernatural forces outside of and hostile to the power of God. It is not a gift from God and it deceives people (also cf. the first commandment).

- Considering that witchcraft was a sin, those who practised it had to be exterminated.

- God's people must seek counselling from God and not from the dead. Seeking advice from sinful sources disturbs the peace of the people and the land.

- Believers need to retain their faith in God, even in the most adverse of circumstances and not only despise witchcraft, but also root it out.

- God deems witchcraft a human fabrication employed to cheat others and is thus powerless.

\section{New Testament principles on witchcraft}

\section{Acts 8:92-5}

The NT reveals that some magicians, sorcerers and diviners considered themselves gods. Thus, it is not surprising that in Acts 8:9-25 the Samaritan sorcerer projected himself as a god and was treated by his followers as such. We read in verse 9 and 10 that Simon the Sorcerer boasted of his own greatness and how all the people, both high and low, proclaimed and praised him as a great power. In his spiritual blindness, the sorcerer thought that he could buy God's power from Peter and Philip. Peter's response, in verse 20, clearly demonstrates that there is no room for witchcraft in a Christian's heart. He says:

May your money perish with you because you thought you could buy the gift of God with money! You have no part or share in this ministry because your heart is not right before God. (Nyirongo 1997:189)

Many traditions relate to Simon the Sorcerer and a variety of allegations have been levelled at him, namely, that he was the founder of Gnostic heresies; that he went to Rome to pervert the Christian doctrine; and that he lost a miracle contest against Peter. At any rate, this Simon of Samaria did indeed practice sorcery in the city of Samaria, to the amazement of its citizens, which explains why they referred to him as the great power from God (Wiersbe 1996).

It is evident in Scripture that wherever God sows his true believers, Satan will inevitably sow his counterfeits (Mt 13:24-30, 36-43; Vincent 2002). This was true of the ministry of John the Baptist (Mt 3:7ff) and Jesus (Mt 23:15, 33; Jn 8:44) as well as that of Paul (Ac 13:6ff; 2 Cor 11:1-4, 13-15). The enemy comes like a lion to devour and when that approach fails, he comes as a serpent to deceive. Satan's tool in this case was a sorcerer named Simon. Simon's sorcery was driven by Satan, whilst Philip's miracles were empowered by God and to the glory of Christ.

Both Philip and Simon performed miracles: Simon by demonic power and Philip by divine power. Simon boasted and welcomed acclaim, whereas Philip proclaimed Christ and although Simon's magic evoked amazement, Philip's ministry converted people to Christ (Wiersbe 1996).

Luke does not clearly indicate whether Simon was eventually saved and it is difficult to be dogmatic about such an issue. Yet seven facts suggest that Simon was probably not born again. The verb 'believe' [pisteuo] does not always refer to converted faith and Simon's faith could have been like that of the demons, referred to in James 2:19, merely a form of intellectual assent. Furthermore, faith based on signs is not a trustworthy faith (cf. Jn 2:23-25; 4:48) and Luke makes no mention of Simon receiving the Holy Spirit (Ac 8:17-18). Simon continued to have a self-centred interest in the display of miraculous power, as is evident from verses 18-19. The verb 'repent' [metanoia], used in verse 22, normally relates to lost people. Furthermore, the word 'perish' [apollumi], used in verse 20, is strong and relates to the use of 'perish' in John 3:16. The description of Simon in Acts 8:23 is more the description of a lost man than of one who is saved (cf. Deut 29:18). However, one cannot be dogmatic on this point and besides; the Lord knows who his children are (Wiersbe 1996). 


\section{Principles from Acts 8:9-25}

- Witchcraft is used to deceive people and is evil.

- Witchcraft leads to self-exaltation and claims the place of God in life.

- Witchcraft promotes demonic power and as such opposes the will of the Holy Spirit.

- Those who practice witchcraft have to be rebuked, through God's Word, so that they may see Christ and his love.

\section{Acts 13:8-25}

Acts 13:8-25 demonstrates that the people of the New Testament continued participating in witchcraft. These verses also recount Barnabas and Paul's encounters with such people. Barnabas and Paul went to Cyrup and it should kept in mind that Barnabas was a native of Cyrup (Ac 4:36). It would have been typical of his gracious heart for him to want to share the treasures of Jesus first with his own people (cf. Walvoord \& Zuck 1985). Cyrup was a Roman province famous for its copper mines and its shipbuilding industry. The governor of Cyrup was Sergius Paulus. These were intensely superstitious times and most great men - even intelligent men like Sergius Paulus - retained private wizards and fortune-tellers who performed magic and spells.

During his first missionary journey to Cyrup, Paul met a Jewish magician by the name of Elymas who opposed the faith and attempted to turn the proconsul against it. The Greek word used here is Elumas [Magos] or Elymas the magician. According to Louw and Nida (1989:545) [magos] is someone who practices magic and witchcraft.

Wiersbe (1996) explains that the interpretation of the name Elymas is somewhat problematic, but that it is probably a Semitic word meaning sorcerer and was given to or adopted by him as a nickname. Elymas comes from the Arabic root alim, which means to sage or is derived from the Aramaic haloma which means interpreter of dreams (Keener 1993).

Irrespective of the meaning of the name, Elymas or Elymas made the mistake of attempting to compete with the Gospel through his own mystical and ridiculous pretensions to supernatural power, in order to turn the proconsul from the faith (Scott 1968:58). Verses 10-12 explain how the sorcerer was punished because witchcraft practices were forbidden even in the early church. Paul's response to Elymas is another clear illustration of how a Christian should perceive witchcraft. Paul said to Elymas:

You are a child of a devil, an enemy of everything that is right, you are full of all kinds of deceit and trickery. Will you not stop preventing the right ways of the Lord? (Ac 13:10-12)

The phrase 'you are the enemy of everything that is right' may refer to Elymas's general moral opposition to all that was good and just (Keener 1993). The phrase 'enemy of all righteousness' may imply that Elymas had set himself up as an enemy of God and that he was filled with deceit [dolos] and trickery [panourgia]. The original meaning of the word dolos was 'bait', by which something or someone was lured into a trap and this was exactly what Elymas did to Sergius Paulus - he deceived him with his false claims. He then added to his evil ways by not only tricking the proconsul, but also perverting the straight path of the Lord with his attempt to divert the official from the Gospel.

\section{Principles from Acts 13:8-25}

- Christians should not view witchcraft as a positive practice.

- Witchcraft is the enemy of all that is right.

- Witchcraft practices lure people from what is true to what is false.

\section{Acts 19:19}

Acts 19:19 relates how people repented through faith. It states that those 'who had practiced sorcery brought their scrolls together and burned them publicly'. Ephesus was regarded as the centre of black magic and occult practices (Life Application Bible 1989:2002). The famous statue of Artemis was erected there and this magical gibberish was considered to have enormous power (Polhill 2001). It is not surprising then that Paul encountered magic in Ephesus, nor is it strange that his converts there had been involved in such practices. Magic was part of Ephesian culture.

Despite the popularity of Jewish magicians, people recognised that Paul's Jesus could not be manipulated in the way that lower spirits could, which led them to faith and repentance of their sins. Many also brought their magical papyri to be burned. Magical papyri were magical incantations, rolled up in small cylinders or lockets and worn as amulets around the neck. They were so common in Ephesus that rolls of these formulas were referred to as Ephesia grammata or Ephesian writings (Keener 1993).

These magical papyri consisted of various spells that often invoked the names of foreign gods and employed several kinds of gibberish (Polhill 2001). These ancient magicians were syncretistic and would borrow terms from any religion that sounded sufficiently strange to be deemed effective. The attempt to lure people to their magical tricks was unsuccessful. People believed God's Gospel and burnt all that was associated with magical practices.

\section{Principles from Acts 19:19}

- New believers should radically turn away from magical practices.

- Regardless of how strong the mixture, magical potions cannot replace the work and the power of the Holy Spirit and the Word of God.

- Blessings can only come from God and cannot be found in magical formulas and potions.

\section{Revelation 9:20-21; 21:8 and 22:15}

The final reference to witchcraft comes from Revelation 9, which warns that lack of repentance from sin, including the sin of witchcraft, will lead to destruction. The book gives an 
account of the sounding of the fifth and sixth trumpets; the appearance that preceded them as well as the events that were to follow. The sin of witchcraft, which includes sorcery, falls under the sixth trumpet. This dreadful judgement also pertained to those considered to be idolaters, murderers, sorcerers, fornicators and thieves.

These sins are the crimes of the anti-Christ and his agent and although God has revealed his wrath from heaven against them they remain obstinate, hardened, impenitent - and judicially so - for they must be destroyed (Henry 1996:2475). The sixth trumpet teaches that when God's judgement is on earth, he expects its inhabitants to repent of sin and enter into righteousness. The sins that are cited in verse 21 , including the sin of witchcraft, have no place in the worship of our Lord (The Interpreters Bible 1995:437) and whoever persists in active opposition to God will meet with his judgement (Beasley-Murray 1974:314). The list of those who will be in the lake that burns with fire and brimstone are the fearful, whoremongers, sorcerers, idolaters and all liars. None of these evildoers have any place in the great consummation and will be punished with the second death (i.e. the death following their physical death).

In Chapter 22 sorcerers, fornicators, murderers, idolaters and everyone who loves and practices falsehood are said to be outside the city of the New Jerusalem (Beasley-Murray 1974:341). This particular chapter gives a description of the heavenly state of the church ( $R v$ 22:1-5), a confirmation of this and all the other visions of this book ( Rv 22:6-19), and then concludes in Revelation 22:20-21. Verse 15 is often cited as proof that these evil practitioners are just outside the city gate vainly seeking admission (The Interpreters Bible 1995:547).

\section{Principles from Revelation 9:20-21; 21:8 and 22:15}

- The sins of witchcraft will be destroyed.

- Witchcraft has no place in the worship of our Lord.

- Those who practice witchcraft and other sins will be condemned to eternal death. Although adherents to witchcraft are difficult to identify, the church must employ sermons and conferences on witchcraft to guide these believers towards repentance.

- All evildoers, including witches have no place in the great consummation.

- Whoever practices witchcraft has no place amongst believers.

\section{Summary of the New Testament principles regarding witchcraft}

- Witchcraft is a means of deceiving people and as such is evil and the enemy of all that is right.

- Witchcraft leads to self-exaltation and claims the place of God in life. Regardless of how strong the mixture, magical potions cannot replace the work and the power of the Holy Spirit and the Word of God.

- Witchcraft has no value in life. It is not part of the Christian faith and is a pagan form of worship.
- Witchcraft promotes demonic power and thus opposes the will of the Holy Spirit.

- Whoever becomes involved in witchcraft must receive counselling from the Word and be guided to see Christ's love so that they may come to realise how this sin will be eradicated and rendered powerless before God. Witchcraft, however, becomes a problem when its practitioners are not Christian. This would necessitate the church to launch outreach programmes, to inform the community on the dangers of witchcraft and perhaps offer guidance, through biblical principles, to allay the community's concerns over witchcraft.

- God's punishment will be now and eternal.

\section{A picture of Scriptural teaching on witchcraft}

The above study of the principles identified in Scriptural passages shows God's condemnation of witchcraft, because it is driven by Satan and is in no way a gift from God. In addition, these biblical principles also demonstrate how God will punish, now and eternally, practitioners of this sin who do not repent. Even in the most adverse circumstances of life, witchcraft must never be considered a viable option. Seeking blessing in the power of witchcraft is futile. Blessings are gifts from God only and God will never employ witchcraft to bestow a blessing. This study shows the similarity in view between modern-day Africans and the people in the Old and New Testament. As Nyirongo (1997:186) points out, Africans have at some point or another regarded witchcraft of value for personal gain, just like the OT and the NT people consulted, practiced and considered witchcraft of value to advance their own interests.

The most compelling truth, derived from the principles identified in the Word of God, is that witchcraft is in no way part of the Christian faith and may in no way be practised. Witchcraft is in direct opposition to the triune God and thus challenges his sovereignty. Whoever challenges God shall be destroyed, together with his or her activities.

Current believers do, however, have the assurance that victory is only in the name of Christ, because he overcame the powers of darkness on the Cross (Koch 1976:85). Paul also confirms this in Col 2:15, when he says, 'Christ has disarmed the principalities and powers and made a public example of them, triumphing over them in his cross'. God gave his church the necessary tools to triumph over darkness. Ephesians 6:10-20 contains the leading elements of the classic mode of spiritual warfare. The essential issue in combating evil is the consistent and repeated turning from darkness to light in the midst of assailing darkness (Powlison 1995:36).

\section{Conclusion}

The main aim of this article was to obtain biblical principles on witchcraft. The research has clearly shown how witchcraft has been a serious problem amongst God's people throughout the history of humankind. For that matter, Africans can in no 
way justify the value of witchcraft to their lives (cf. Nyirongo 1997:186). Similarly, Africans cannot claim confusion over the condemnation of witchcraft because the principles derived from both the Old and New Testament clearly demonstrate God's denouncement and punishment of witchcraft. The church cannot condone such practices in any way and must make a concerted effort to oppose it in every way. As previously noted in this article, the belief in witchcraft is found in all Africans societies and it is the responsibility of the church to counsel those members who still struggle with this issue. On balance the principles derived from the Bible may serve as part of the foundation to resolve and clear up any uncertainty about witchcraft in the lives of Africans.

\section{Acknowledgements Competing interests}

The authors hereby declare that they did not have any financial or personal relationship(s) which may have inappropriately influenced them in writing this paper.

\section{Authors' contributions}

D.K. (North-West University Potchefstroom Campus) was the project leader and wrote the manuscript and R.S. (NorthWest University Potchefstroom Campus) was responsible for the editing of the manuscript.

\section{References}

Achtemeier, P.J., 1985, Harper's Bible dictionary, 1st edn., Harper \& Row, Logos Research Systems Inc., San Francisco.

Beasley-Murray, G.R., 1974, New century Bible, Nelson Press, London.

Carson, D.A., 1994, New Bible commentary: 21st century edition, revised edition of: the new Bible commentary, 3rd edn., Intervarsity Press, Leicester, Downers Grove, the

Clements, R.E., 1972, The Cambridge Bible commentary, University Press, Cambridge. http://dx.doi.org/10.1177/144078337200800120

De Vries, B.A., 2010, Study guide for systematic theology 1 DST 111, Mukhanyo Theological College, South Africa.

Easton, M., 1996, Easton's Bible dictionary, Logos Research Systems Inc., Oak Harbor WA.

Girdlestone, R.B., 1998, Synonyms of the Old Testament: their bearing on Christian doctrine, Logos Research Systems Inc., Oak Harbor, WA.
Hayes, S., 1995, 'Christian response to witchcraft and sorcery', Missionalia 3, 339-354. Henry, M., 1996, Matthew Henry's commentary on the whole Bible: complete and unabridged in one volume, Hendrickson, Peabody, MA.

Jamieson, R., Fausset, A.R. \& Brown, D., 1997, A commentary, critical and explanatory on the OT and NT on spine: critical and explanatory, Logos Research Systems Inc., Oak Harbour, WA.

Keener, C.S., 1993, CD-ROM, The IVP Bible background commentary: NT, Intervarsity Press, Downers Grove, IL.

Keil, C.F. \& Delitzsch, F., 2002, Commentary on the OT, CD-ROM, Hendrickson, Peabody, MA.

Kgatla, S.T., 1995, 'Remaining prophetic in a time of reconstruction and development', Report delivered during the Annual General Meeting of the Institute for Contextual Theology in 1995, pp. 1-45, Braamfontein.

Khunou, M., 2001, 'Break the demonic chain through Jesus', Sowetan, viewed 04 February 2004, from http://www.citypress.co.za

Koch, K.E., 1976, Occult bondage and deliverance, Kregel, Grand Rapids, MI.

Kotze, Z., 2007, 'The evil eyes as witchcraft technique in the Hebrew Bible', Journal for Semetics 16(1), 141-149.

Kotze, Z., 2008, 'The witch in Psalm 59', OTE 21(2), 383-390.

Letšosa, R.S., 2005, A relevant liturgy for the reformed churches in synod Midlands, PU for $\mathrm{CHE}$, Potchefstroom.

Louw, J.P. \& Nida, E.A., 1989, Greek-English lexicon of the NT based on Semitic domains, 2 vols, United Bible Societies, New York.

Mbiti, J.S., 1991, Introduction to African religion, Heineman Educational Books, USA.

Nyirongo, L., 1997, The gods of Africa or the God of the Bible: the snares of African traditional religion in Biblical perspective, $\mathrm{PU}$ for $\mathrm{CHE}$, Potchefstroom.

Phillips, A., 1973, The Cambridge Bible commentary on the new English Bible, University Press, Cambridge.

Polhill, J.B., 2001, Acts: The new American commentary, CD-ROM, vol. 26, Broadman \& Holman Publisher, Nashville.

Powlison, D., 1995, 'Power encounter: reclaiming spiritual warfare', Baker Books, Grand Rapids, MI.

Richards, L., 1991, 'The Bible reader's companion: included index', Victor Books, Wheaton, IL.

Scott, B.W., 1968, Letters on demonology and witchcraft, S.R. Publisher, Wakefield.

Spence, H.D.M. \& Exell, J.S., 1950, The pulpit commentary, Williams B. Eerdmans, Grand Rapids, MI.

Strong, J., 1996, The exhaustive concordance of the Bible: showing every word of the text of the common English version of the canonical books, and every occurrence of each word in regular order, (electronic edn.), Woodside Bible Fellowship, Ontario.

Trapido, M., 2010, 'Make witchcraft a criminal offence', Mail and guardian, viewed 04 February 2012, from http://wwwmailandguardian.co.za

Van Rooy, J.A., 1973, 'Witches and Wizards in the Light of Scripture', Missionalia 1 136-138.

Vincent, M.R., 2002, Word studies in the NT, CD-ROM, Logos Research Systems Inc, Bellingham, WA.

Walvoord, J.F. \& Zuck, R.B., 1985, The Bible knowledge commentary: an expository of the Scriptures, CD-ROM, Victor Books, Wheaton, IL.

Wiersbe, W.W., 1996, The Bible expository outlines on the NT, CD-ROM, Victor Books, Wheaton, IL.

Wiseman, O.B.E., 1988, The Tyndale OT commentaries, Intervarsity Press, Downers Grove, IL. 